\title{
ARTIFICIAL NESTING STRUCTURES FOR GREAT BLUE HERONS
}

\author{
ALLAN P. SANDILANDS, P.O. Box 147, Plattsville, Ontario, NOJ 1 SO.
}

Heron use of man-made structures for nesting sites is well documented. Wiese described nesting platforms at Avery Island, Louisiana, that were used by Little Blue Herons, Great Egrets, Snowy Egrets, and Louisiana Herons for over 70 years. ${ }^{5}{ }^{3}$ Sandilands reported a Green Heron nesting in a Wood Duck box and Gunter recorded Great Blue Herons nesting on duck blinds. ${ }^{4}{ }^{2}$

Luther Marsh Wildlife Management Area, located in southwestern Ontario, has supported a Great Blue Heron colony since the 1840-ha impoundment was created in 1952. Boyer and Devitt reported 25-30 Great Blue Heron nests annually from 1955 to 1958 in a drowned white cedar (Thuja occidentalis) and elm (UImus spp.) forest. ${ }^{1}$ Nesting habitat for herons continually decreased in this heronry as standing dead timber was removed by spring ice movement or blown into the marsh. In order to maintain a breeding population of Great Blue Herons, the Grand River Conservation Authority constructed multiple and single artificial nesting structures in February 1972.

The multiple-nesting structure consisted of nine unpeeled red pine (Pinus resinosus) poles (varying in length from 6 to $10 \mathrm{~m}$ ) approximately $2 \mathrm{~m}$ apart. The poles were connected at four points along their length by $2.5 \times 15-\mathrm{cm}$ planks. Poles on the exterior of the structure were braced with steel cable connected to metal fence posts driven into the lake sub- strate. Thirteen 1.3-m square nesting baskets were placed in the structure, three of them containing nesting material. The sides of the baskets were constructed of $2.5 \times 15-\mathrm{cm}$ lumber and the bottom was $2.5-\mathrm{cm}$ mesh galvanized wire strengthened with five $5 \times 5-\mathrm{cm}$ strips of lumber.

The four single-nesting structures consisted of a single pole 9-11 $\mathrm{m}$ in height with a nesting basket at the top. The poles were braced with four-six poles pushed obliquely into the lake's bottom. Thirty additional single-nesting structures were erected during February 1973 and 33 were located on an island approximately $200 \mathrm{~m}$ from the herony in August 1974.

The single-nesting structures on the island and the multiple-nesting structure were failures because the herons avoided them. The singlenesting structures in the lake were partially successful. Great Blue Herons readily adapted to nesting in the single-nesting structures over water, but these structures were unstable due to the physical environment. The substrate of the marsh was deep muck that provided little support in spite of the brace poles and wires. Ice depth frequently exceeded $1 \mathrm{~m}$, so nesting structures were often pulled out when the ice shifted in the spring.

In 1972, all four of the original single-nesting structures were utilized as nesting sites by Great Blue Herons. By the 1973 nesting season, 22 nesting structures were available, 


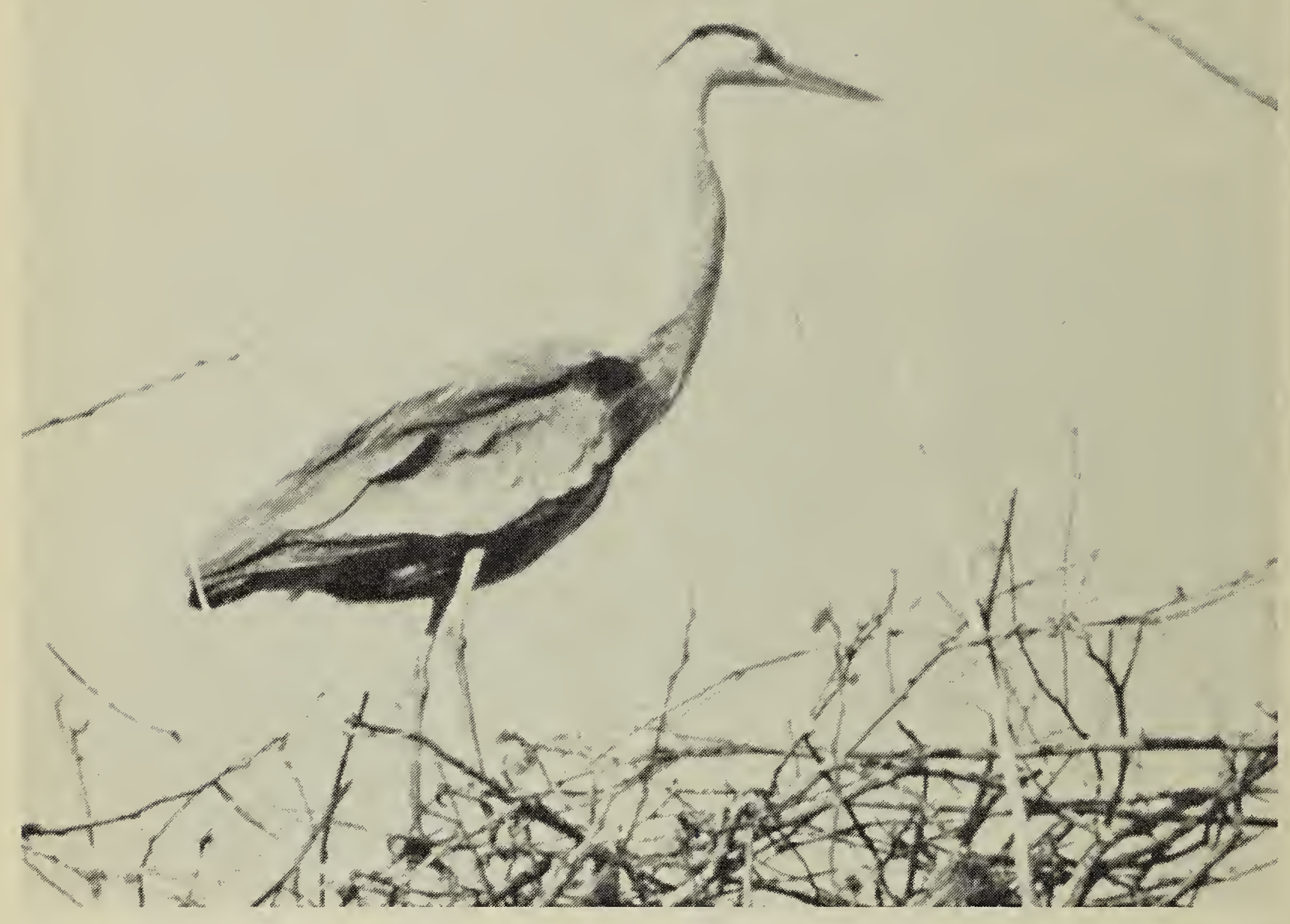

Great Blue Heron.

Larry A. Morgotch

and seven of the 12 nesting pairs of herons used them. Eleven nesting structures were standing in 1974 and held six of the seven nests. In 1975 the remaining seven artificial nesting structures were utilized with no natural sites being selected. This heronry was abandoned in 1976 in favour of another existing Great Blue Heronry in secluded, natural habitat.

The experiments at Luther Marsh demonstrate that, under certain circumstances, Great Blue Herons will adapt to nesting baskets placed on single tall poles. In areas where they can be firmly anchored, artificial nesting structures may become a significant tool in Great Blue Heron management.
${ }^{1}$ BOYER, G. F. and O. E. DEVITT. 1961. A significant increase in the birds of Luther Marsh, Ontario, following fresh-water impoundment. Can. Field-Nat. 75(4):225-237.

${ }^{2}$ GUNTER, G. 1956. Duck blinds as nesting sites for Great Blue Herons on the south Texas coast. Auk $73(1): 131$.

${ }^{3}$ MCILHENNY, E. A. 1912. How I made a bird city. Country Life in America 22(9):23-28.

${ }^{4}$ SANDILANDS, A. P. 1977. Green Heron nesting in a Wood Duck box. Auk 94(2):390.

${ }^{5}$ WIESE, J. H. 1976. Courtship and pair formation in the Great Egret. Auk 93(4):709-724. 